\title{
Identification of potential targets for differentiation in human leukemia cells induced by diallyl disulfide
}

\author{
HUI LING ${ }^{1,2^{*}}$, JIE HE $^{1,2^{*}}$, HUI TAN ${ }^{1,2}$, LAN YI $^{1}$, FANG LIU $^{1,2}$, XIAOXIA JI ${ }^{1}$, YOUHUA WU ${ }^{3}$, \\ HAOBIN HU ${ }^{1,2}$, XI ZENG $^{1,2}$, XIAOHONG AI ${ }^{3}, \mathrm{HAO} \mathrm{JIANG}^{3}$ and $\mathrm{QI} \mathrm{SU^{1,2 }}$ \\ ${ }^{1}$ Key Laboratory of Tumor Cellular and Molecular Pathology, College of Hunan Province, \\ Cancer Research Institute, University of South China; ${ }^{2}$ Hunan Province Cooperative Innovation Center for \\ Molecular Target New Drug Study, Hunan Provincial Education Department; ${ }^{3}$ The First Affiliated Hospital, \\ University of South China, Hengyang, Hunan 421001, P.R. China
}

Received October 22, 2016; Accepted December 27, 2016

DOI: $10.3892 /$ ijo.2017.3839

\begin{abstract}
Diallyl disulfide (DADS) is a primary component of garlic, which has chemopreventive potential. We previously found that moderate doses $(15-120 \mu \mathrm{M})$ of DADS induced apoptosis and $\mathrm{G} 2 / \mathrm{M}$ phase cell cycle arrest. In this study, we observed the effect of low doses $(8 \mu \mathrm{M})$ of DADS on human leukemia HL-60 cells. We found that DADS could inhibit proliferation, migration and invasion in HL-60 cells, and arrested cells at $\mathrm{G}_{0} / \mathrm{G}_{1}$ stage. Then, cell differentiation was displayed by morphologic observation, NBT reduction activity and CD11b evaluation of cytometric flow. It showed that DADS induced differentiation, reduced the ability of NBT and increased CD11b expression. Likewise, DADS inhibited xenograft tumor growth and induced differentiation in vivo. In order to make sure how DADS induced differentiation, we compared the protein expression profile of DADS-treated cells with that of untreated control. Using high resolution mass
\end{abstract}

Correspondence to: Professor Qi Su, Key Laboratory of Tumor Cellular and Molecular Pathology, College of Hunan Province, Cancer Research Institute, University of South China, 28 Western Changshen Road, Hengyang, Hunan 421001, P.R. China

E-mail: suqi1945@163.com

Professor Hao Jiang, The First Affiliated Hospital, University of South China, Hengyang, Hunan 421001, P.R. China

E-mail: jhao16859@163.com

"Contributed equally

Abbreviations: DADS, diallyl disulfide; RhoGDI2, RhoGDP dissociation inhibitor 2; CTR, calreticulin; AML, acute myeloid leukemia; ATRA, all-trans retinoic acid; ATO, arsenic trioxide; NBT, nitroblue tetrazolium; PMN, polymorphonuclear; H\&E, haematoxylin and eosin; CapLC-ESI-Q-TOF-MS, capillary liquid chromatographyelectrospray ionization-quadrupole-time of flight-mass spectrometry; TBS, Tris-buffered saline; TBST, Tris-buffered saline/Tween-20; PCNA, proliferating cell nuclear antigen

Key words: diallyl disulfide, leukemia, potential targets, proteomics, differentiation spectrometry, we identified 18 differentially expressed proteins after treatment with DADS, including four upregulated and 14 downregulated proteins. RT-PCR and western blot assay showed that DJ-1, cofilin 1, RhoGDP dissociation inhibitor 2 (RhoGDI2), Calreticulin (CTR) and PCNA were decreased by DADS. These data suggest that the effects of DADS on leukemia may be due to multiple targets for intervention.

\section{Introduction}

Acute myeloid leukemia (AML), a malignant and aggressive neoplasm, is not sensitive to chemotherapy. AML is the most common acute leukemia in adults, and its incidence is 3-4/100,000 per year (1). Although most patients with standard induction chemotherapy can achieve complete remission, the recurrence rate is still high, and more than half of the patients die of the disease (2). The medical community continues to make progress in the molecular signaling pathways of AML, however, still no significant improvement on treatment has been shown.

In addition to the ability of cell proliferation and apoptosis resistance, undifferentiated state is characteristic of most cancer cells, especially leukemia cells. Cell differentiation has many aspects on complex regulatory networks, including transcriptional, post-transcriptional and epigenetic regulation of gene expression. The lineage-specific genes and cell growth and death related genes are involved in the process of maturation. To induce cancer cell differentiation is regarded as an alternative method leading to cell death and proliferation inhibition. Differentiation therapy has primarily been used in the treatment of AML, especially with all-trans retinoic acid (ATRA) (3). The second clinically useful agent in AML is arsenic trioxide (ATO) (4). In spite of the outstanding success of ATRA treatment, a large number of patients had recurrence on account of ATRA resistance (5). Retinoic acid syndrome is a relatively common and serious complication that acute promyelocytic leukaemia patients may occur after treated with ATRA and/or ATO (6). Although widespread myeloid differentiation inducing compounds have been described, including alkaloids, flavonoids and polyphenols, but their clinical efficacy in the treatment of AML still remains to be 
further investigated $(3,7)$. Hence, it is indispensable to find promising induction compounds, that are relatively non-toxic and effective, and can be used for clinical purposes.

Diallyl disulfide (DADS) is a kind of organosulfur compound from allium plants such as garlic. DADS had antitumor role in a variety of tumors (8), and was found non-toxic in vivo according to the experimental data (9). Therefore, as a recognized anticancer agent, which inhibits cancer cell growth and invasion, DADS has a good outlook for adjuvant therapy in clinical application.

We previously showed that moderate amount of DADS (15-120 $\mu \mathrm{M})$ can markedly suppress the growth in human AML HL-60 cells (10), induce apoptosis (11) and G2/M arrest (12). In this study, we found that $8 \mu \mathrm{M}$ DADS induced differentiation of HL-60 cells in vitro and in vivo expriments. On this basis, using high resolution mass spectrometry, we screen and obtain molecules showing statistically differential expression between DADS-treated and untreated cells. Eighteen proteins were identified, including four upregulated and 14 downregulated proteins. The discovery of these molecules is conducive to reveal unknown anti-leukemia mechanisms of DADS as a potential differentiating agent.

\section{Materials and methods}

Cell culture and cell proliferation assay. Human leukemia cell line HL-60 was from the Cancer Research Institute, Xiangya Medical College, Center South University in China. Cells were cultivated in RPMI-1640 medium with $10 \%$ fetal bovine serum (FBS), $100 \mu \mathrm{g} / \mathrm{ml}$ streptomycin, and $100 \mathrm{U} / \mathrm{ml}$ penicillin $\mathrm{G}$ in a humidified atmosphere of $5 \% \mathrm{CO}_{2}$ and $95 \%$ air at $37^{\circ} \mathrm{C}$.

Cells $\left(3 \times 10^{4}\right)$ were seeded in 96-well plates and treated with Tween-80 (control) or different concentrations (4, 8, 16, 32, 64 and $128 \mu \mathrm{M}$ ) of DADS (Fluka Co., Milwaukee, WI, USA), and resolved in Tween- 80 at $8 \mathrm{~g} / \mathrm{l}$ and stored at $-20^{\circ} \mathrm{C}$ ) for $72 \mathrm{~h}$. HL-60 cells were covered with MTT solution $(5 \mu \mathrm{g} / \mathrm{ml})$ at $37^{\circ} \mathrm{C}$ for $3 \mathrm{~h}$. Formazan crystals shaped by the living cells were resolved in absolute ethyl alcohol and scanned in a scanning multi-well spectrophotometer (Spectra Max 190) at $570 \mathrm{~nm}$. According to inhibition rate $(\mathrm{IR})=\left(1-\mathrm{OD}_{\text {treatment group }} / \mathrm{OD}_{\text {control group }}\right) \times 100 \%$, inhibition rate was calculated.

Wright-Giemsa stain and NBT reduction assay. Before induction of differentiation by DADS, HL-60 cells were kept at a logarithmic growth rate and seeded at a density of $1 \times 10^{4}$ cells/well. After exposure to $8 \mu \mathrm{M}$ DADS for $72 \mathrm{~h}$, we collected cells by cytospin centrifugation, stained them with Wright-Giemsa stain and observed them by microscopy. Moreover, the treated cells were pelleted by centrifugation at $300 \mathrm{x}$ g for $5 \mathrm{~min}$. Differentiation of HL-60 cells was assessed by adding $200 \mu \mathrm{l}$ of cell suspension each well to a solution containing $2 \mathrm{mg} / \mathrm{ml}$ of NBT(nitroblue tetrazolium) and $0.24 \mathrm{mg}$ / $\mathrm{ml}$ of PMA in phosphate-buffered saline (PBS). The incubation process for $1 \mathrm{~h}$ at $37^{\circ} \mathrm{C}$, was stopped by adding $0.4 \mathrm{ml}$ cold $2 \mathrm{M}$ $\mathrm{HCl}$. The formazan product was centrifugated at $700 \mathrm{x} \mathrm{g}$ for $10 \mathrm{~min}$, and dissolved in $200 \mu \mathrm{l}$ DMSO. The absorbance of the solution was analyzed at $570 \mathrm{~nm}$.

Immunofluorescence of CD11b. Immunofluorescence was accomplished to confirm subcellular localization of a general myeloid differentiation marker CD11b (ab24874). After treatment with DADS $(8 \mu \mathrm{M})$ for three days, HL-60 cells were collected by centrifugation. Drops of cells were coated on slides and incubated at room temperature for $30 \mathrm{~min}$, fixed with $4 \%$ polyoxymethylene, then permeabilized with $0.5 \%$ Triton X-100 in PBS for $15 \mathrm{~min}$. After that, cells were blocked with goat serum for $30 \mathrm{~min}$ to minimize nonspecific binding of the primary antibody. The CD11b antibody (1:100 dilution) was applied at $37^{\circ} \mathrm{C}$ for $1 \mathrm{~h}$ followed by 5 -min washes in PBS, three times. FITC anti-rabbit IgG (ab6717) were used to determinate CD11b. Images were captured using a Life AMAFD1000 fluorescent microscope and measured with Image EVOS software (both from Life Technologies Corp., Bothell, WA, USA).

Tumor xenograft. All animal procedures were carried out according to the National Institutes of Health guidelines for experimental animal use. The protocol was authorized by the Committee on the Ethics of Animal Experiments of the University of South China. Two-month-old Kunming species mice were obtained from the Laboratory Animal Center of University of South China. A total of $5 \times 10^{6}$ HL-60 cells were injected into the left renal capsule membrane of mice. DADS were injected through the tail vein of mice, at a concentration of 21,42 and $84 \mathrm{mg} / \mathrm{kg}$ body weight every day for 5 days. Control mice were injected with same volume of vehicle ( $0.9 \%$ saline solution). The tumor size was measured from day 6 after injection. The volume of the tumor was calculated by the following formula: Volume $=$ Length $\mathrm{x} \mathrm{Width}^{2} \mathrm{x} 0.5$. Inhibitory rate $=[($ Volume of control tumors - volume of drug tumors)/volume of control tumors] x $100 \%$. Tumor-burdened kidneys were fixed with $70 \%$ of ethanol for $24 \mathrm{~h}$, embedded in paraffin, sectioned at $5 \mu \mathrm{M}$, and stained with H\&E staining. Then cell morphological changes were observed using an optical microscope. All surgery was performed under sodium pentobarbital anesthesia, and we made every effort to minimize suffering.

Cell cycle assay by flow cytometric detection. Cell cycle analysis was confirmed by flow cytometry. Briefly, HL-60 cells were plated in $75 \mathrm{~cm}$ dishes. After treated by DADS (4, 8 and $16 \mu \mathrm{M}$ ) for 3 days, HL-60 cells were collected, centrifuged and washed with PBS. Next, $70 \%$ ethanol was added to fix the cells overnight at $4^{\circ} \mathrm{C}$. Then after removing ethanol, and PBS washing twice, cells were digested with RNAase A for $1 \mathrm{~h}$ at $37^{\circ} \mathrm{C}$, and stained with $800 \mu \mathrm{l} \mathrm{PI}(50 \mu \mathrm{g} / \mathrm{ml})$ in the dark for $1 \mathrm{~h}$ at $4^{\circ} \mathrm{C}$. In the end, the DNA contents of cell cycle were analysed using a flow cytometer (Beckman Coulter EPICS-XL).

Transwell migration and invasion assays. The migration and invasion assays were determined using 24-well transwell chambers ( $8 \mu \mathrm{M}$; Corning). For the migration assay, HL-60 cells were resuspended in serum-free RPMI-1640 medium and $100 \mu \mathrm{l}$ cell suspension $\left(1 \times 10^{6}\right.$ cells) were seeded into the upper chambers. RPMI-1640 (500 $\mu \mathrm{l})$ containing 10\% FBS was added to the bottom chambers. After incubation for $24 \mathrm{~h}$, the migrated cells on the lower membrane surface were fixed with $4 \%$ paraformaldehyde for $30 \mathrm{~min}$ and stained with $0.1 \%$ crystal violet for $15 \mathrm{~min}$, and calculated under an invert microscope. The invasion assay protocol was the same as that 
of the migration assay except that the upper chambers were first coated with $1 \mathrm{mg} / \mathrm{ml}$ Matrigel.

Protein preparation. The total protein from both untreated cells (control) and cells treated with $8 \mu \mathrm{M}$ DADS for $72 \mathrm{~h}$ were extracted with lysis buffer (Amersham Biosciences) containing $8 \mathrm{M}$ urea, 4\% CHAPS, $40 \mathrm{mM}$ Tris, $1 \%$ DTT, $1 \mathrm{mM}$ PMSF, $0.5 \%$ IPG buffer.

$2 D E$ and silver stain. Protein samples (200 $\mu \mathrm{g}$ each) were mixed with hydration solution (8 M Urea, 2\% CHAPS, $0.5 \%$ IPG buffer, $18 \mathrm{mM}$ DTT, trace bromophenol blue) and rehydrated with $18 \mathrm{~cm}$ IPG strip ( $\mathrm{pH} 4-7)$ in the isoelectric focusing (IEF) cell followed by $1 \mathrm{D}$ IEF in a maximum current of $60 \mu \mathrm{A} / \mathrm{IPG}$ strip. The strips were equilibrated in buffer $\mathrm{A}$ (8 M urea, 2\% SDS, 50 mM Tris- $\mathrm{HCl}$, pH 6.8, 30\% glycerol, $1 \%$ SDS and $0.2 \%$ DTT) for $15 \mathrm{~min}$ and in buffer B (8 M urea, $50 \mathrm{mM}$ Tris- $\mathrm{HCl}, \mathrm{pH} 6.8,30 \%$ glycerol, $1 \%$ SDS and $3 \%$ iodoacetamide) for $15 \mathrm{~min}$. The $2 \mathrm{D}$ electrophoresis of the strips was accomplished on $12 \%$ SDS-PAGE gel prepared. The gels were fixed in fixing solution ( $40 \%$ methanol, $10 \%$ glacial acetic acid) at room temperature for $30 \mathrm{~min}$, sensitized in sensitizing solution (30\% ethanol, $0.2 \%$ sodium thiosulfate, $6.8 \%$ sodium acetate), washed with double distilled water, stained with silver staining $(0.25 \%$ silver nitrate), and then developed in developing solution ( $2.5 \%$ sodium carbonate, $0.084 \%$ ormaldehyde) until protein point appeared completely, followed by terminated solution (1.5\% EDTA) immediately.

Image analysis and statistical significance. Gels were scanned using the Tsinghua Ziguang scanner D2000 (Tsinghua Ziguang Co.) and assayed using PDQuest 7.1 analysis software (Bio-Rad), according to the the manufacturer's instructions. Quantity of each spot was standardized by total valid spot intensity. Protein spots were regarded as differentially expressed only if they exhibited at least a 2.0-fold difference in abundance between control and treatment.

In situ digestion of protein. Protein points were cut down from gels by silver stain, decolored using decolorizing solution $\left[30 \mathrm{mM} \mathrm{K}{ }_{3} \mathrm{Fe}(\mathrm{CN})_{6}, 100 \mathrm{mM} \mathrm{Na} \mathrm{S}_{2} \mathrm{O}_{3}\right.$ ]. Next, samples were reducted and alkylated with $100 \mathrm{mM} \mathrm{NH}_{4} \mathrm{HCO}_{3}(10 \mathrm{mM}$ DTT in it). After enzymolysis using TPCK-Trypsin enzyme solution (TPCK-Trypsin $0.02 \mathrm{~g} / 1,20 \mu \mathrm{M} \mathrm{HCl}, 40 \mathrm{mM} \mathrm{NH}_{4} \mathrm{HCO}_{3}$, $10 \%$ acrylonitrile) for $16 \mathrm{~h}$, samples were extracted with extraction solution (5\% trifluoroacetic acid, $50 \%$ acrylonitrile) for $1 \mathrm{~h}$.

CapLC-ESI-Q-TOF-MS analysis. All of the data were from Micromass Q-Tof micromass spectrometer. CapLC elution peptide fragments were assayed by MS and MS/MS after entering mass spectrometry ion source: positive ion detection mode, the source temperature at $80^{\circ} \mathrm{C}$, cone hole voltage $60 \mathrm{~V}$, nozzle voltage $3000 \mathrm{~V}$, the detector voltage of $2700 \mathrm{~V}$, instrument level (MS) scanning range was set to 200-1600. Conversion between primary MS and secondary MS controlled by mother ionic strength and electric charge, secondary MS analysis to analyze the primary ion of the set threshold value; each analysis of the four greatest intensity mother ion using Glu-fib pieces of tandem calibration instrument. MassLynx software picked each MS and MS/ MS data under the elution of salt concentration converted into PKL file by proteinLynx software containing primary mother ion size $(\mathrm{m} / \mathrm{z})$, intensity and the size of the pieces of the secondary ion, which was inputted into database (NCBI), and searched using the cascade mass spectrum data function (MS/MS ions search) of the Mascot software (Matrix Science, Ltd., London, UK). Database search parameters are: carbamidomethyl $(\mathrm{C})$ is the fixed modification, trypsin the lyase, allow two as the maximum missed cleavages, the peptides Mw tolerance 1.2, the fragment ions Mw tolerance 0.6 , and 50 results are shown. We confirmed protein identification on the basis of peptide identification as long as the peptide score (Mowse score) was higher than its threshold.

RT-PCR analysis. Total RNA was extracted from cells using TRIzol reagent (Invitrogen). The RT-PCR kit (Thermo Fisher Scientific) was used to perform reverse transcription, and the PCR kit (Promega) was applied to implement PCR analysis. Primer sequences were as follows: DJ-1, F, 5'-GTC AGC AGC TTC TAC CTG GAC-3' and R, 5'-GTG TTG TTC TGA GAG TGA AAG GCA CG-3'; cofilin 1, F, 5'-CAA GAA GGC GGT GCT CT-3' and R, 5'-ACA AAG GTG GCG TAG GG-3'; $\beta$-actin, F, 5'-ACA CTG TGC CCA TCT ACG AGG GG-3' and R, 5'-ATG ATG GAG TTG AAG GTA GTT TCG TGG AT-3'; RhoGDI2, F, 5'-GGG GCA TCA TCA AGA GCA-3' and R, 5'-CCA GGC AGT TGT GGG AGT-3'; $\beta$-actin, F, 5'-ACA CTG TGC CCA TCT ACG AGG GG-3' and R, 5'-ATG ATG GAG TTG AAG GTA GTT TCG TGG AT-3'; calreticulin (CTR), F, 5'-GGA AGA TGA GGA GGA AGA TGT C-3' and R, 5'-CAG GAA GGA GAG CAG ATG AAA T-3'; $\beta$-actin, F, 5'-GGA CCT GAC TGA CTA CCT C-3' and R, 5'-TAG TCG TTC GTC CTC ATA C-3'; PCNA, F, 5'-AGT CAG TCT TCA GGA TGT GCT-3' and R, 5'-TGA CAT GGG ATG CTA GGC TT-3'; $\beta$-actin, F, 5'-TGG CAT CCA CGA AAC TAC CT-3' and R, 5'-TCA CCT TCA CCG TTC CAG TT-3'. The PCR products were assayed on a $2 \%$ agarose gel having ethidium bromide. Densitometric quantitation of PCR products was identified using the Labwork analysis software. The ratio of target gene to $\beta$-actin was quantified to get the relative fold-changes in gene expression.

Western blot analysis. Protein samples (3 $\mu \mathrm{g}$ each) were analysed by $12 \%$ SDS-PAGE, and transferred onto PVDF membranes. The membranes were blocked for $2 \mathrm{~h}$ at room temperature in blocking buffer (3\% skim milk/0.1\% Tween-20/TBS), and then incubated with the primary antibodies (DJ-1 antibody and $\beta$-actin; Santa Cruz Biotechnology, Inc., Santa Cruz, CA, USA; cofilin 1, RhoGDI2, CTR and PCNA; Abcam) at $4^{\circ} \mathrm{C}$ overnight. After washing with $0.1 \%$ Tween-20/TBS (TBST) for $10 \mathrm{~min}$, three times, the blots were covered with HRP-conjugated secondary antibody (Abcam) in blocking buffer for $2 \mathrm{~h}$. The membranes were washed with TBST, the blot was assayed by the super signal ECL detection system.

Statistical analyses. All experiments were repeated three times, and data are shown as the mean \pm SEM. SPSS 17.0 software was used to perform statistical analyses. Statistical analyses were evaluated using one-way ANOVA. A P-value $<0.05$ was considered statistically significant. 
A

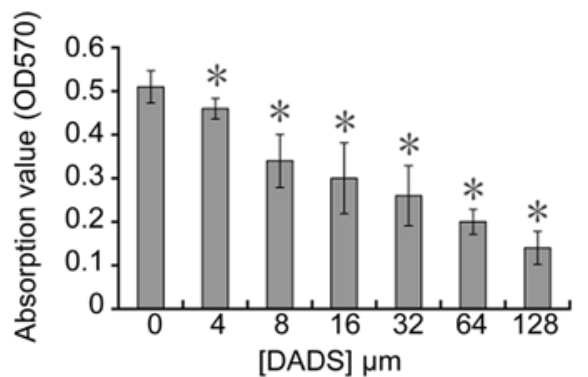

$\mathrm{B}$

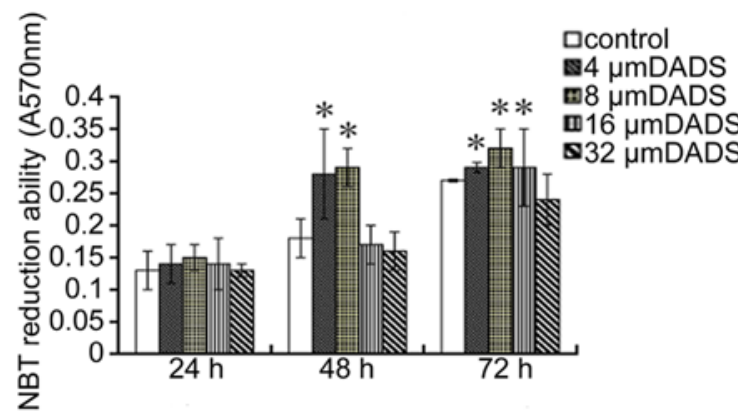

C

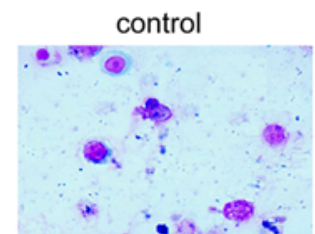

$\mathrm{D}$
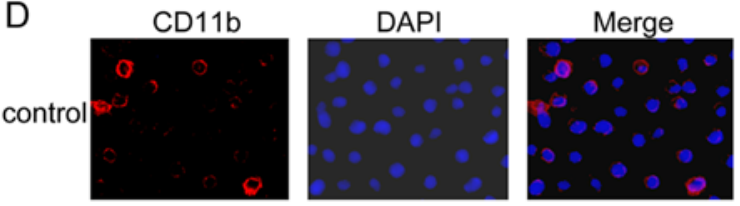

$8 \mu \mathrm{m}$
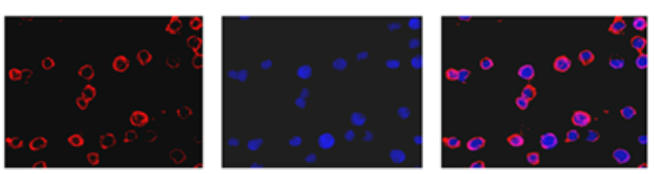

Figure 1. Antiproliferative and differentiation induction effects of DADS on human leukemic cell line HL-60. (A) Effect of DADS on cell viability of cell line HL-60. Cells $\left(3 \times 10^{4}\right)$ were treated with different concentration of DADS $(4,8,16,32,64$ and $128 \mu \mathrm{M})$ and control $(0.1 \%$ Tween- 80 only) for $72 \mathrm{~h}$ and the viable cells were analyzed by MTT assay. (B) Effect of DADS on NBT reduction in HL-60 cells. HL-60 cells were treated with 4, 8, 16 and $32 \mu \mathrm{M}$ DADS for 24,48 and $72 \mathrm{~h}$. Control cells were exposed to $0.1 \%$ Tween- 80 . Differentiation of HL-60 cells was identified by the decrease in NBT absorbance at $570 \mathrm{~nm}$. The values are the means \pm SEM of three determinations. ${ }^{*} \mathrm{P}<0.05$ compared with control. (C) Role of $8 \mu \mathrm{M}$ DADS on morphological change of HL-60 cell differentiation. HL-60 cells were treated with DADS for $72 \mathrm{~h}$. Control cells were exposed to $0.1 \%$ Tween- 80 . We collected cells by centrifugation, stained with Wright-Giemsa stain and observed using light microscopy (x400). (D) Effect of DADS on expression of cell surface differentiation marker CD11b. HL-60 cells were treated with DADS $(8 \mu \mathrm{M})$ for $72 \mathrm{~h}$ and then were fixed in $4 \%$ formaldehyde/PBS and permeabilized with $0.5 \%$ Triton X-100. CD11b was showed by immunofluorescence (red, left panel). The DNA-intercalating dye DAPI was used to recognize cell nuclei (blue, center panel). The right panel displayed a merged image to highlight the nuclear pool of CD11b.

\section{Results}

Antiproliferative and differentiation induction effect of DADS on $H L-60$ cells. Proliferation activity of human leukemic cell line HL-60 was analyzed using MTT assay and trypan blue dye exclusion test incubating with DADS at different
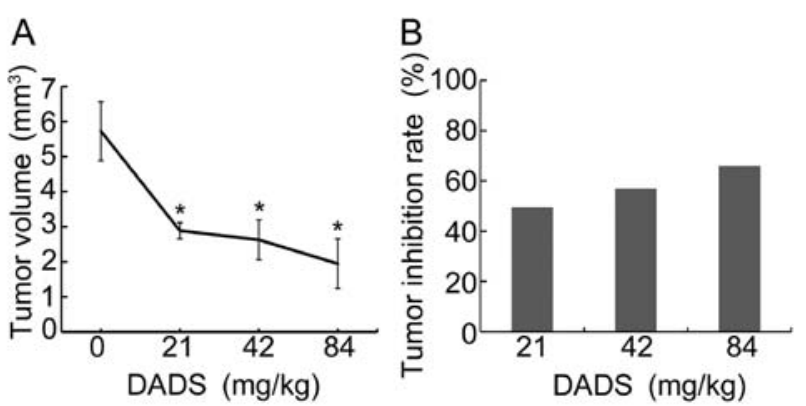

C
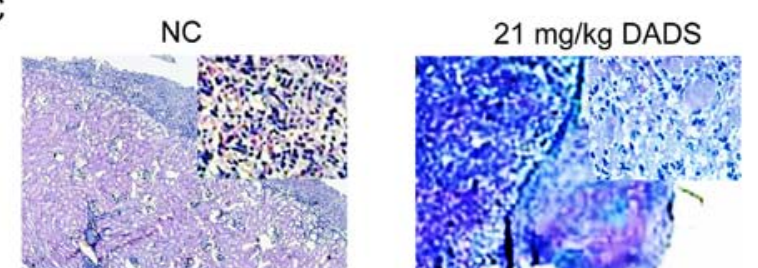

$42 \mathrm{mg} / \mathrm{kg}$ DADS

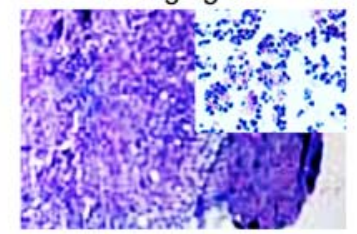

$84 \mathrm{mg} / \mathrm{kg}$ DADS

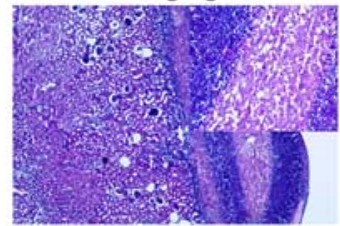

Figure 2. DADS induced inhibition effect of HL-60 cell tumorigenesis in vivo. HL-60 cells were subcutaneously injected into the left renal capsule membrane of mice. DADS were injected through the tail vein of mice, at a dose of 21,42 and $84 \mathrm{mg} / \mathrm{kg}$ body weight every day for 5 days. Same volume of vehicle ( $0.9 \%$ saline solution) were injected into control mice. (A) Tumor volume was measured from day 6 after injection. $n=5$, "p $<0.05$. (B) Tumor inhibitory rate from volume change of xenograft tumor by DADS of 21,42 and $84 \mathrm{mg} / \mathrm{kg}$ body weight every day for 5 days. This experiment was done twice with similar results. (C) H\&E staining of tissue sections from DADS treated and control tumors. A representative image is displayed.

doses. A dose-dependent cytotoxicity was observed at $72 \mathrm{~h}$ DADS-treatment with growth IR of 18, 30, 37, 48, 58 and $70 \%$ for $4,8,16,32,64$ and $128 \mu \mathrm{M}$, respectively compared to untreated cells as shown in Fig. 1A.

As shown in Fig. 1C, untreated HL-60 cells showed typical myeloid leukemia cell morphology with big oblong nucleus, small cytoplasm, and large ratio of nucleus to cytoplasm, while $8 \mu \mathrm{M}$ DADS induced a granulocytic lineage of differentiation (arrow). Moreover, to ascertain the role of DADS on differentiation, we investigated the NBT reduction assay and the expression of CD11b in HL-60 cells. As shown in Fig. 1B and Table I, compared to untreated control, $8 \mu \mathrm{M}$ DADS could markedly induce the differentiation. In Fig. 1D, the expression of the CD11b increased after treated with $8 \mu \mathrm{M}$ DADS for 3 days as compared to the control.

$D A D S$ induces growth inhibition and differentiation effect on HL-60 cells in vivo. To detect the role of DADS in leukemia in vivo, HL-60 cells were injected into mice and the growth of xenograft tumors was measured after DADS injection for five days. DADS tumors grew much slower than control tumors (Fig. 2A). The tumor inhibition rate rose from 49.5, 56.9 to $65.9 \%$ by DADS of 21,42 to $84 \mathrm{mg} / \mathrm{kg}$ body weight every day for 5 days compared to control tumors (Fig. 2B), suggesting that DADS controlled xenograft tumor progression. 
Table I. DADS-induced differentiation effect in HL-60 cells.

Classification of cells

\begin{tabular}{lccccc}
\cline { 2 - 5 } Group & Promelocyte & Myelocyte & Metamelocyte & Band cell and PMN & Induction differentiation rate (\%) \\
\hline HL-60 cells & $0.85 \pm 0.006$ & $0.145 \pm 0.008$ & 0 & 0 & 0 \\
$8 \mu$ M DADS & $0.063 \pm 0.150$ & $0.150 \pm 0.021$ & $0.113 \pm 0.036$ & $0.673 \pm 0.025^{\mathrm{a}}$ & $91.3 \pm 2.1^{\mathrm{a}}$
\end{tabular}

${ }^{\text {a }}<0.05$ vs. HL-60 cells. PMN, polymorphonuclear.
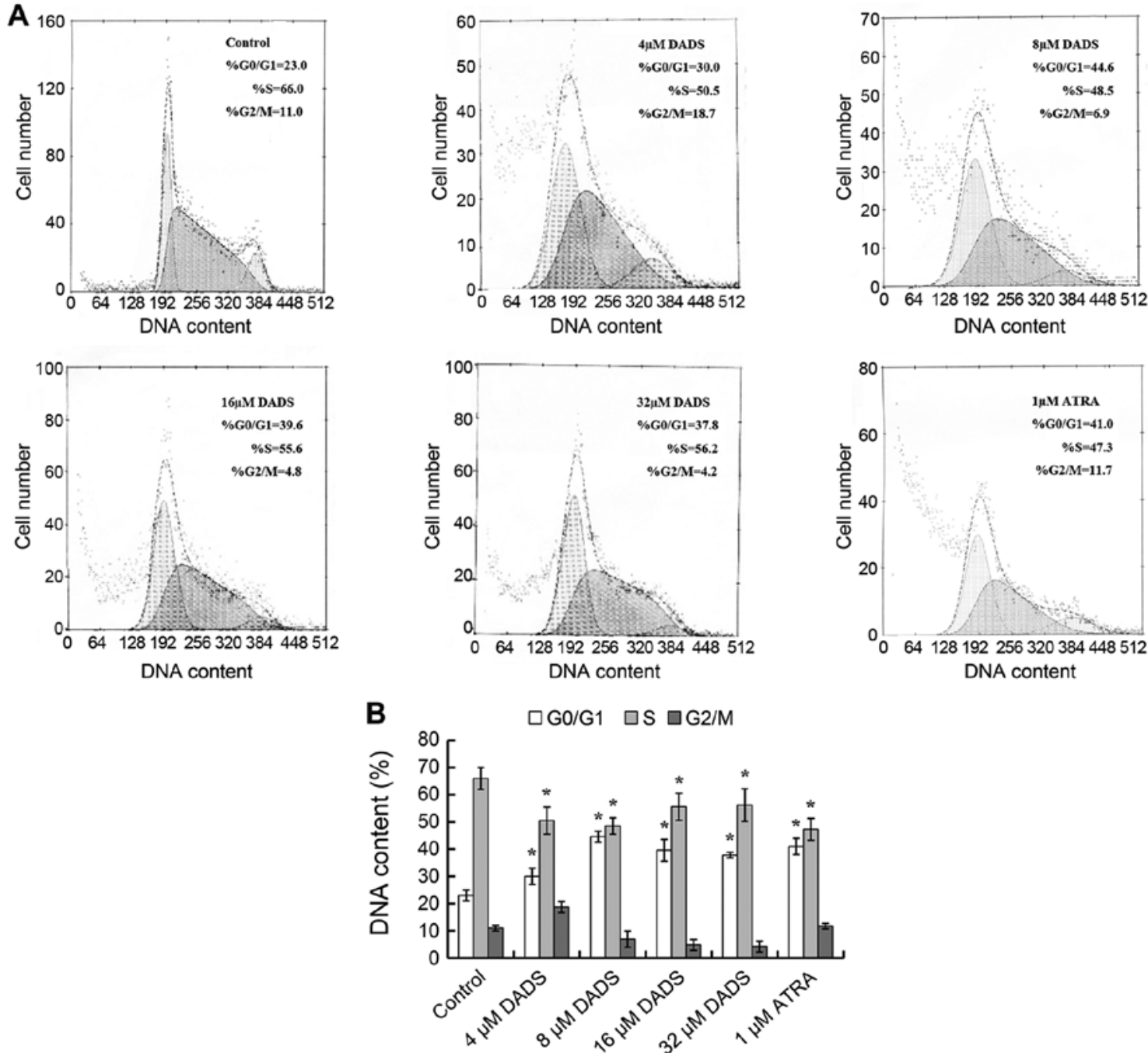

Figure 3. Analysis of cell cycle arrest induced by DADS in HL-60 cell line. (A) Histogram showing the distribution of cell populations in different phases of cell cycle with DADS treatment in HL-60 cells as measured by flow cytometry analysis after staining the cells with ethidium bromide. We treated $1 \times 10^{5}$ cells $/ \mathrm{ml}$ with $0,4,8,16$ and $32 \mu \mathrm{M}$ of DADS for 3 days. (B) Graphical representation of distribution of cell populations in different phases of the cell cycle, in $4,8,16$ and $32 \mu \mathrm{M}$ of DADS treated HL-60 cells for 3 days, respectively, is shown. DADS induced the $\mathrm{G}_{0} / \mathrm{G}_{1}$ phase proportion and decreased the $\mathrm{S}$ phase proportion of HL-60 cells. ATRA $(1 \mu \mathrm{M})$ was as positive control. Data obtained by at least three independent experiments. "P $<0.05$ vs. control.

H\&E staining results revealed that the differentiation effect was induced by $21 \mathrm{mg} / \mathrm{kg}, \sim 42 \mathrm{mg} / \mathrm{kg}$ DADS in the HL- 60 cells under the renal capsule membrane. Optical microscopy (x40) showed that the volume of the cells reduced, dye of nuclei was obviously lighter, with kidney-like or lobulated nucleus, and the nucleo-cytoplasmic ratio of HL-60 cells was fairly small, which presented typical myeloblastic morphology, with a granulocytic lineage differentiation. Whereas, $84 \mathrm{mg} / \mathrm{kg}$
DADS induced necrosis in HL-60 cells clearly under renal capsule membrane (Fig. 2C).

The effect of DADS on cell cycle of HL-60 cells. As shown in Fig. 3, DNA contents from flow cytometry analysis indicated that among the untreated HL-60 cells, $66 \%$ were distributed in S phase, $23 \%$ were accumulated in $\mathrm{G}_{0} / \mathrm{G}_{1}$ phase, and only $11 \%$ were in $\mathrm{G} 2 / \mathrm{M}$ phase. Increase of $\mathrm{G}_{0} / \mathrm{G}_{1}$ cells and corresponding 
Table II. Differential expression proteins induced by DADS in HL-60 cells.

\begin{tabular}{|c|c|c|c|c|}
\hline $\begin{array}{l}\text { SPOT } \\
\text { no. }\end{array}$ & Accession no. & Protein name & $\begin{array}{l}\text { Theoretical } \\
\mathrm{Mr}(\mathrm{kDa}) / \mathrm{pI}\end{array}$ & $\begin{array}{l}\text { Expression } \\
\text { alteration }\end{array}$ \\
\hline 1 & P27797 & Calreticulin (precursor) & $48.1 / 4.29$ & Downregulated \\
\hline 2 & P28066 & $\begin{array}{l}\text { Proteasome subunit } \alpha \text { type } 5 \text {, } \\
\text { Proteasome zeta chain multicatalytic } \\
\text { endopeptidase complex zeta chain }\end{array}$ & $26.4 / 4.74$ & Downregulated \\
\hline 3 & P12004 & Proliferating cell nuclear antigen, PCNA, cyclin & $28.8 / 4.57$ & Downregulated \\
\hline 4 & O14805 & RNA-binding protein regulatory subunit, DJ-1 protein & $19.8 / 6.33$ & Downregulated \\
\hline 5 & P52566 & Rho GDP-dissociation inhibitor 2, Ly-GDI & $22.99 / 5.10$ & Downregulated \\
\hline 6 & P10668 & Cofilin, non-muscle isoform, CFL1 & $18.5 / 8.16$ & Downregulated \\
\hline 7 & P00918 & Carbonic anhydrase II & $29.1 / 6.86$ & Downregulated \\
\hline 8 & P04075 & $\begin{array}{l}\text { Aldolase A, muscle-type aldolase, } \\
\text { Fructose-bisphosphate aldolase A }\end{array}$ & $39.3 / 8.39$ & Downregulated \\
\hline 9 & P60174 & Triosephosphate isomerase & $26.5 / 6.51$ & Downregulated \\
\hline 10 & Q06830 & $\begin{array}{l}\text { Peroxiredoxin } 1 \text {, } \\
\text { Thioredoxin peroxidase } 2\end{array}$ & $22.1 / 8.27$ & Downregulated \\
\hline 11 & P30048 & $\begin{array}{l}\text { Thioredoxin-dependent peroxide reductase, } \\
\text { mitochondrial (precursor), peroxiredoxin } 3\end{array}$ & $27.7 / 7.68$ & Downregulated \\
\hline 12 & P54819 & $\begin{array}{l}\text { Adenylate kinase isoenzyme } 2 \\
\text { ATP-AMP transphosphorylase }\end{array}$ & $26.3 / 7.85$ & Downregulated \\
\hline 13 & Q14590 & Zinc finger protein 93 & $1.63 \mathrm{e}+003$ & Downregulated \\
\hline 14 & P04406 & Glyceraldehyde-3-phosphate ehydrogenase & $4.77 e+004$ & Downregulated \\
\hline 15 & Q05315 & $\begin{array}{l}\text { Eosinophil lysophospholipase, } \\
\text { Charcot-Leyden crystal protein, } \\
\text { Galactin-10 }\end{array}$ & $16.3 / 6.80$ & Upregulated \\
\hline 16 & Q14103 & $\begin{array}{l}\text { Heterogeneous nuclear ribonucleoprotein D0, } \\
\text { hnRNP D0, AUF1 }\end{array}$ & $38.4 / 7.61$ & Upregulated \\
\hline 17 & Q15149 & $\begin{array}{l}\text { Plectin } 1 \text {, } \\
\text { Hemidesmosomal protein } 1\end{array}$ & $531.7 / 5.73$ & Upregulated \\
\hline 18 & P13804 & Electron transfer flavoprotein $\alpha$-subunit & $35.1 / 8.62$ & Upregulated \\
\hline
\end{tabular}

PCNA, proliferating cell nuclear antigen; CFL1, cofilin 1.

decrease of S cells were dose-dependent when HL-60 cells were treated by $4,8,16$ and $32 \mu \mathrm{M}$ DADS. It was detected that $\mathrm{G}_{0} / \mathrm{G}_{1}$ cells were raised to the peak $(44.6 \%, \mathrm{P}<0.05)$, although $\mathrm{S}$ phase cells declined to a minimum $(48.5 \%, \mathrm{P}<0.05)$ respectively at the concentration of $8 \mu \mathrm{M}$, similar to effects induced by ATRA.

DADS inhibits HL-60 cell migration and invasion. We treated cells with $8 \mu \mathrm{M}$ DADS for 12 and $24 \mathrm{~h}$, and observed the effects of DADS on migration and invasion of leukemia HL-60 cell line. As showed in Fig. 4A, relative to HL-60 control cells, there was a remarkable decline in the migratory capacity of HL-60 cells in $8 \mu \mathrm{M}$ DADS for 12 and $48 \mathrm{~h}$. As demonstrated in Fig. 4B, the amount of cells that crossed the membrane in the DADS-treatment group were markedly lower than those in the control group. These data suggest that DADS significantly suppressed migration and invasion activities of HL-60 cells.

Identification of differential expression proteins by 2-DE and $M S$. To detect differential expression proteins induced by DADS, HL-60 cells were exposed to $8 \mu \mathrm{M}$ DADS for $72 \mathrm{~h}$.
Proteins from DADS-treated and untreated cells were resolved by $2-\mathrm{DE}$, respectively, and the gels were stained with silver to make visible the protein spots in the 2-DE gels. Two typical 2-DE maps from DADS-treated and untreated groups are exhibited in Fig. 5A and B, respectively. By comparing the ratio of each spot in the gels, it was identified as distinguishingly expressed that protein spots have constant differences ( $\geq 2$-fold) between DADS-treated group and the untreated group in triplicate experiments. All differential protein spots were resected from stained gels and digested with trypsin. Eighteen differently expressed proteins were identified on the basis of CapLC-ESI-Q-TOF-MS and database query with NCBI (Table II). These protein spots were marked with arrows in Fig. 5A and B. Compared with the untreated group, the expression levels of four proteins were upregulated, while the expression levels of the other 14 proteins were downregulated in DADS-treated group.

Verification of DADS-induced differential expression genes in HL-60 cells. Among the identified proteins, DJ-1, cofilin 1, RhoGDI2, CTR and PCNA displayed significantly differential 

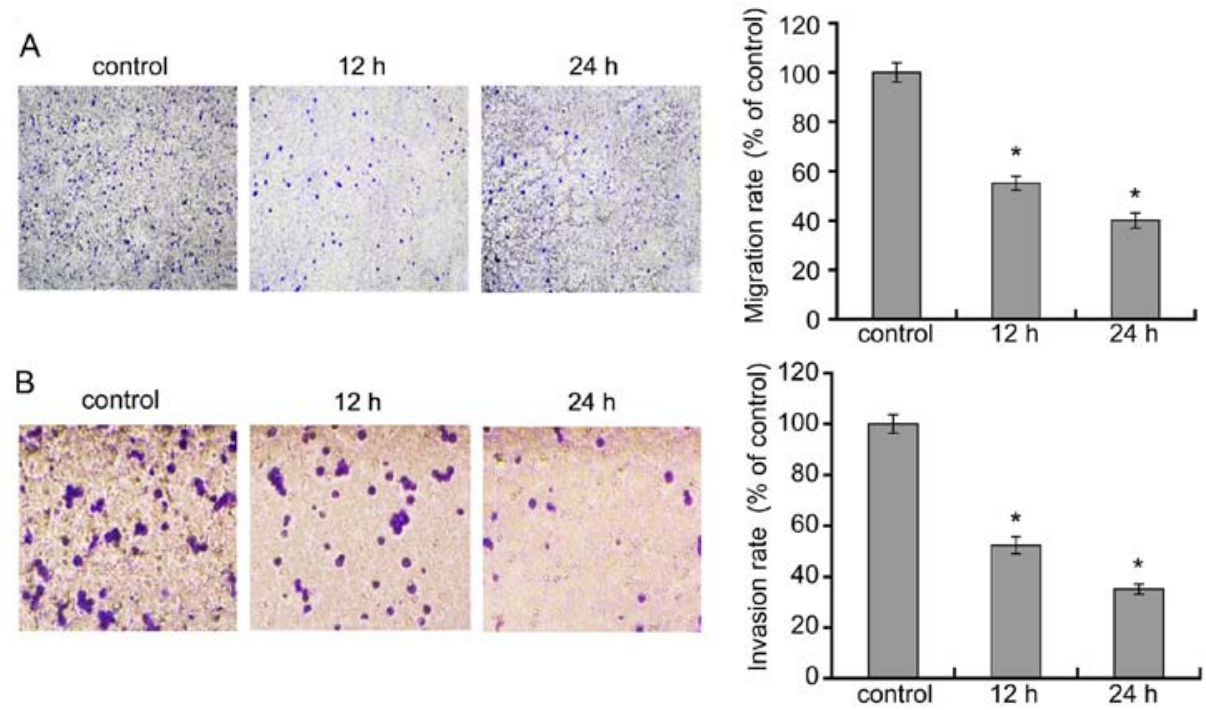

Figure 4. Effects of DADS on migration and invasion of HL-60 cells. Indicated DADS concentrations were added to HL-60 cells for 12 and 24 h. (A) Cell migration and invasion were examined using the Transwell migration and invasion assays. Migration rate was indicated as the ratio of migration cell numbers between treated and untreated HL-60 cells. (B) Invasion rate was estimated by the ratio of means of cell numbers between treated and untreated cells. ${ }^{*} \mathrm{P}<0.05$ vs. control.

Table III. The $\mathrm{OD}_{570}$ values and proliferation inhibition ratios of HL-60 cell treated by DADS or ATRA after 3 days.

\begin{tabular}{lcc}
\hline & OD $_{570}$ value & $\begin{array}{c}\text { Proliferation } \\
\text { inhibition ratio (\%) }\end{array}$ \\
\hline Control & $0.51 \pm 0.037$ & \\
$8 \mu \mathrm{M}$ DADS & $0.34 \pm 0.061$ & 30 \\
$1 \mu \mathrm{M}$ ATRA & $0.32 \pm 0.027$ & 34 \\
\hline
\end{tabular}

expression in DADS-treated cells in contrast to untreated cells. Fig. 5C showed a representative comparison of the five proteins. These five proteins were further verified. RT-PCR and western blot analysis were applied to detect the expression pattern of these five genes after HL-60 cells were treated with $8 \mu \mathrm{M}$ DADS for different time periods. As shown in Fig. 6A, the mRNA levels of DJ-1, cofilin 1, RhoGDI2, CTR and PCNA decreased in a time-dependent manner. Accordingly, similar changes in protein levels were also showed in HL-60 cells upon DADS treatment (Fig. 6B). Consequently, DADS-induced changes in gene expression were identified at the transcriptional and translational levels, which agreed with the results from comparative proteomics research.

\section{Discussion}

DADS is the main active component of the anticancer allyl sulphides in garlic, which has been reported to induce proliferation inhibition in many types of tumor cells (8). Our results suggested that DADS inhibited proliferation in leukemia cell line HL-60 and arrested cells in $\mathrm{G}_{0} / \mathrm{G}_{1}$ phase. Previously we confirmed that DADS induced differentiation in human gastric cancer cell line MGC803 by suppressing the activation of ERK1/2 MAP kinase signaling pathway (13). In the present study, we investigated the role of DADS on the differentiation
Table IV. The effect of NBT reduction ability of HL-60 cells treated by DADS or ATRA.

\begin{tabular}{llcc}
\hline & \multicolumn{1}{c}{ Control } & $1 \mu \mathrm{M}$ ATRA & $8 \mu \mathrm{M}$ DADS \\
\hline $24 \mathrm{~h}$ & $0.13 \pm 0.03$ & $0.16 \pm 0.02$ & $0.15 \pm 0.02^{\mathrm{a}}$ \\
$48 \mathrm{~h}$ & $0.18 \pm 0.03$ & $0.28 \pm 0.04$ & $0.29 \pm 0.03^{\mathrm{a}}$ \\
$72 \mathrm{~h}$ & $0.27 \pm 0.002$ & $0.32 \pm 0.03$ & $0.32 \pm 0.03^{\mathrm{a}}$ \\
$96 \mathrm{~h}$ & $1.01 \pm 0.23$ & $1.41 \pm 0.19$ & $1.47 \pm 0.23^{\mathrm{a}}$
\end{tabular}

${ }^{\mathrm{a} P}>0.05$ vs. $1 \mu \mathrm{M}$ ATRA.

in human leukemia HL-60 cells in vitro and in vivo. The cells were examined by Wright-Giemsa staining, NBT reduction, membrane differentiation marker CD11b expression, as well as the distribution of cell cycle phase. Our results show that $8 \mu \mathrm{M}$ DADS results in greater reduction of NBT and expression of granulocytic marker CD11b, and induces HL-60 cell granulocytic lineage of differentiation. Furthermore, DADS induced $\mathrm{G}_{0} / \mathrm{G}_{1}$ arrest as well as growth inhibition and differentiation effect on HL-60 cell xenografts under renal capsule membrane in mice. We compared the cell cycle division in $8 \mu \mathrm{M}$ DADS-treated cells with that in $1 \mu \mathrm{M}$ ATRA-treated cells, it showed that DADS can induce increased $\mathrm{G}_{0} / \mathrm{G}_{1}$ cells and corresponding decrease of $\mathrm{S}$ cells similar to effects induced by ATRA. Except that, we have also found that proliferation inhibition ratios had no significant difference of HL-60 cells between $8 \mu \mathrm{M}$ DADS-treated group and $1 \mu \mathrm{M}$ ATR A-treated group after 3 days (Table III). In addition, NBT reduction value of HL-60 cells had no significant difference in DADS-treated group as compared with that of the $1 \mu \mathrm{M}$ ATRA-treated group for 24, 48, 72 and $96 \mathrm{~h}$ (Table IV). That is to say, $8 \mu \mathrm{M}$ DADS have antiproliferative and differentiation induction effect in HL-60 cells similar to effects induced by $1 \mu \mathrm{M}$ ATRA. These results indicate that DADS may be 


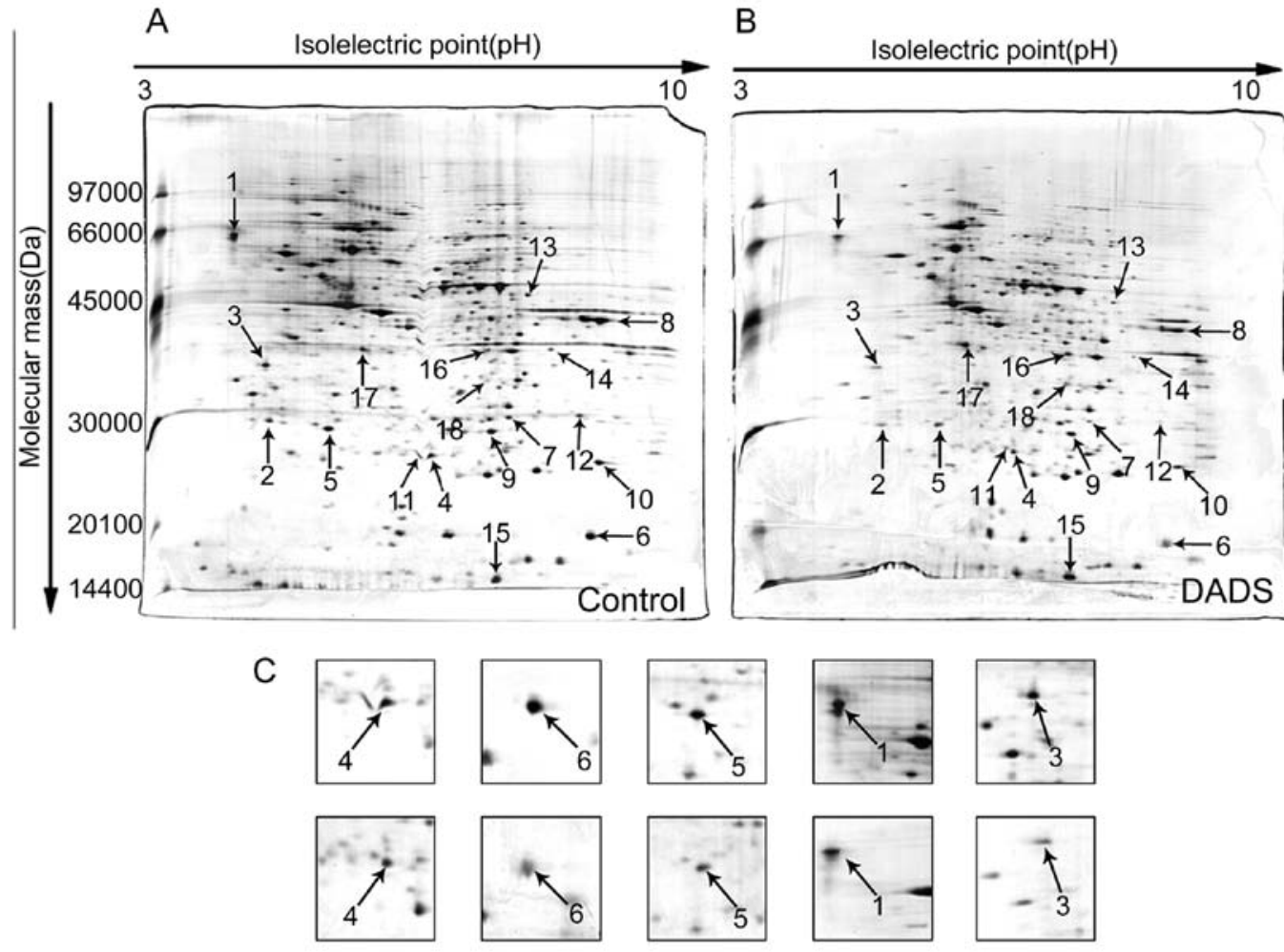

Figure 5. Two-dimensional gel analysis and CapLC-ESI-Q-TOF-MS identification of differential expression proteins between untreated and DADS-treated HL-60 cells. After treated with or without $8 \mu \mathrm{M}$ DADS for $24 \mathrm{~h}$, cells were collected and extracted and separated proteins by 2-DE. Eighteen protein spots displaying prominently differential expression were identified using CapLC-ESI-Q-TOF-MS, and are marked with arrows. Representative 2-DE maps of untreated (A) and DADS-treated (B) HL-60 cells are displayed. (C) Images of four differential expression protein spots, spot 3 (DJ-1), spot 4 (cofilin 1), spot 16 (RhoGDI2), spot 19 (calreticulin, CRT) and spot 23 (PCNA), are revealed between untreated and DADS-treated HL-60 cells.

an anti-leukemia promising induction compound similar to ATRA. The mechanisms concerning the induction of differentiation by DADS have not been thoroughly elucidated.

It is rarely reported that DADS inhibits the migration and invasion of cancer cells, and the molecular mechanisms of DADS have not fully been illuminated. Lai et al reported that DADS can control the migration and invasion in human colon cancer Colo 205 cells (14). This study showed that DADS inhibited migration and invasion of HL-60 cells. However, the precise molecular mechanisms underlying these antimetastatic effects of DADS are not completely clarified.

In the present study, we recognized the potential targets controlled by DADS in HL-60 cells using the comparative proteomics technique. Among the differentially expressed proteins regulated by DADS, DJ-1, cofilin 1, RhoGDI2, Calreticulin and PCNA drew our attention as dysregulation of their expression and function were associated closely with tumorigenesis and progression.

DJ-1 was separated during screening for c-Myc-binding proteins in 1997 (15). Upregulation of DJ-1 expression have been showed in various cancers, including leukemia $(16,17)$. Enhanced levels of DJ-1 expression in cancer cells are positively associated with the severity of cancer with poor prognosis, including invasion and metastasis $(18,19)$. The oxidative status of DJ-1 induces cell proliferation and transformation by regulating PTEN activity (20). The overexpression of DJ-1 and HSP90 $\alpha$, and a loss of PTEN are related to invasion in urothelial carcinoma, Lee et al (19). DJ-1 induces EMT by inhibiting PTEN expression and Akt activation. As a target of p53 during transformation, DJ-1 plays a key part in the p53-mediated AKT pathway and p53-driven oxidative-stress response (21). In this study, it indicated that the decreased level of DJ-1 by DADS may lead to differentiation and suppressing growth and invasion in HL-60 cells.

It displayed that the increased level of cofilin 1 expression was definitely related to the progress of human ovarian cancer differentiation, which demonstrates that the activation of cofilin 1 may accelerate the proliferation and invasion of cancer cells, resulting in the development of ovarian cancer (22). Increase level of cofilin expression induced by diazinon enhanced depolymerization of actin filaments, and then promoted differentiation in neuroblastoma cell line N2a (23). Our data revealed that DADS can decrease cofilin 1 expression in leukemia cells, and demonstrated that inhibition of cofilin 1 activation may be correlated with DADS anti-invasion role in leukemia cells.

RhoGDI 2 is regarded as a family of Rho GTPase dissociate inhibitors (GDIs). GDIs are vital regulators of Rho GTPase function typified by constituting a complex with Rho GTPase, regulating their nucleotide exchange and membrane association. Accordingly, they have a crucial effect on mediating the actin cytoskeleton, cell polarity, microtubule dynamics, membrane transport pathways and transcription factor activity (24). RhoGDI2 has been confirmed as a regulator of tumor metastasis, but its function in cancer is still controversial. RhoGDI2 may conduce to HGF-regulated tumor invasion and metastasis, which can be used as a hopeful target for gastric cancer therapy (25). In hepatocellular carcinoma, RhoGDI2 is upregulated, and has been identified as a proto-oncogene, and 

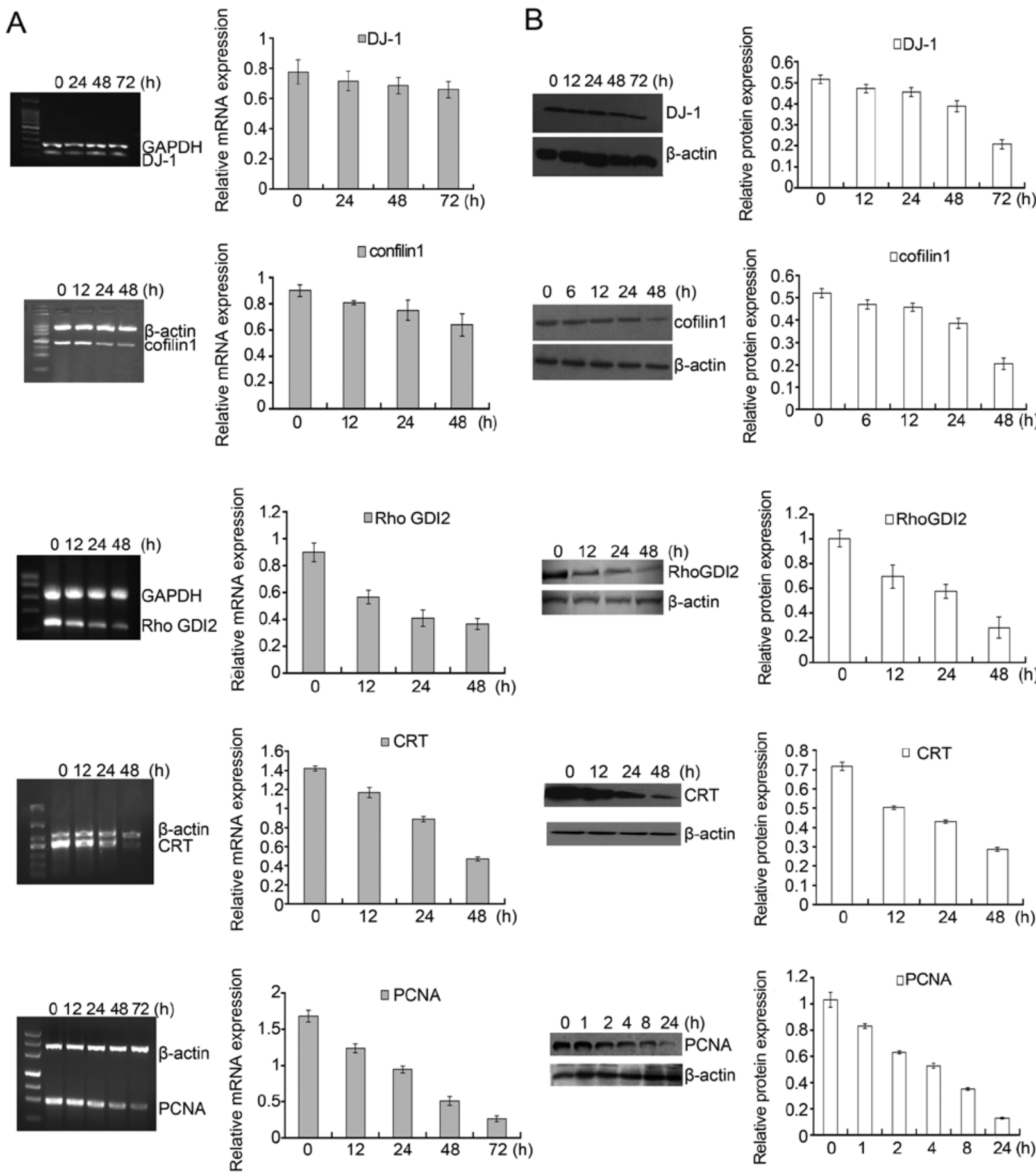

Figure 6. Confirmation of differential expression genes induced by DADS in HL-60 cells. Cells were treated with $8 \mu$ M DADS for indicated times. (A) RT-PCR was used to determine the mRNA expression levels of DJ-1, cofilin 1, RhoGDI2, CTR and PCNA. $\beta$-actin was regarded as an internal control for normalization. (B) Western blot analysis was employed to detect DJ-1, cofilin 1, RhoGDI2, CTR and PCNA protein levels. $\beta$-actin served as a loading control. The relative fold-changes in mRNA or protein level compared with $\beta$-actin controls were analyzed. The results are shown as mean \pm SEM, for three independent experiments. ${ }^{*} \mathrm{P}<0.05$ vs. control.

plays a vital part in tumor growth and invasion (26). RhoGDI2 is reported to have significant effects on cellular apoptosis and metastasis, and they can lead to the adverse progress of AML (27). Rac1 was admitted as the vital co-operator and mediator of RhoGDI2 (28). RhoGDI2 preferentially binds to Rac1 and impacts on its activity, unlike other members of Rho GTPase (28). Another study showed RhoC was also regulated by RhoGDI2 (29). Therefore, RhoGDI2 may be a candidate target for DADS against leukemia cell invasion.
CRT, a multifunctional protein, is mainly located in endoplasmic reticulum and is extremely conserved in different species. The relationship between CRT expression levels and tumorigenesis has been widely analysed in variety of cancers, and most studies have showed that tumor tissues express remarkably higher levels of CRT versus normal tissues (30). It also demonstrates that CRT plays a crucial role in the development of different cancers and the effect of CRT on tumor formation and progression depends upon cell 
types and clinical stages. Upregulated CRT expression may have a significant impact on cancer progression. Regulation of CRT levels has deep effects on cancer cell proliferation and angiogenesis as well as differentiation in neuroblastoma cells; the mechanism that CRT suppresses cell proliferation, and enhances cell differentiation is related to upregulating VEGF expression (31). Lu et al verified that CRT plays a critical role in the control of cell adhesion and migration via various mechanisms (32). In this study, we revealed that DADS decreased CRT expression in leukemia HL-60 cells. We consider that the inhibitory impact on CRT expression induced by DADS may contribute to its anticancer role in leukemia HL-60 cells.

It is reported that different protein profiles were discovered between the melanoma cell line and the melanocytes; the basic form of protein DJ-1, cofilin 1 and calreticulin were more significantly expressed in melanoma A375 cells than in melanocytes (33). When Qin et al compared the expression profiles of differential proteins of retinoic acid (RA) resistant group and sensitive cells, they screened the proteins related to RA resistance by proteomic analysis, the results indicated that DJ-1 and calreticulin are involved in the ATRA resistanceassociated proteins (34).

PCNA is considered as a molecular marker for proliferation, which is based on its function in replication. Over the past decades, further research has given a deeper understanding of PCNA as a coordinator of fundamental cellular role in cell growth, death, and maintenance. Research progress in revealing the potential of targeting PCNA for cancer treatment has not been comprehensively clarified, although the biology of PCNA in proliferation has been thoroughly examined (35). It has been shown that the post-translational modifications of PCNA may take important part in affecting the cellular choice between various pathways, including apoptosis, DNA repair, or the cell cycle checkpoint pathways, for purpose of keeping genomic stability (36). Curcumin decreased PCNA and Rho-A protein expression and inhibited anchorage-independent growth of breast cancer cell lines (37). Similarly, our studies suggest that DADS can inhibit both PCNA and RhoGDI2 expression, suggesting that a decrease in PCNA and RhoGDI2 protein may result in suppression of cell growth.

In conclusion, antitumor effects of DADS may be due to inactivation of oncogenes and activation of tumor suppressors. However, the potential molecular mechanisms controlled by DADS in leukemia are mainly unknown. Accordingly, we identified DADS-induced differential expression proteins in leukemia cells using the comparative proteomics approach in this study. These findings are worthy not only of unveiling potential targets for DADS, but also further proving its antitumor mechanisms in future studies, which conduces to clinical treatment for leukemia.

\section{Acknowledgements}

This study was supported by the National Natural Science Foundation of China (grant nos. 81100375, 31201027 and 81400117), the Hunan Provincial Natural Science Foundation of China (grant no. 2015JJ4042), the Patency Foundation of Innovation Platform of Hunan Provincial University of China (grant no. 11K057). The study was performed using equipment purchased with funding from the construction program of the key discipline in Hunan Province, China (Basic Medicine Sciences in University of South China).

\section{References}

1. Schlenk RF: Post-remission therapy for acute myeloid leukemia. Haematologica 99: 1663-1670, 2014.

2. Mrózek K, Marcucci G, Nicolet D, Maharry KS, Becker H, Whitman SP, Metzeler KH, Schwind S, Wu YZ, Kohlschmidt J, et al: Prognostic significance of the European LeukemiaNet standardized system for reporting cytogenetic and molecular alterations in adults with acute myeloid leukemia. J Clin Oncol 30: 4515-4523, 2012.

3. Morceau F, Chateauvieux S, Orsini M, Trécul A, Dicato M and Diederich M: Natural compounds and pharmaceuticals reprogram leukemia cell differentiation pathways. Biotechnol Adv 33: 785-797, 2015.

4. Sui M, Zhang Z and Zhou J: Inhibition factors of arsenic trioxide therapeutic effects in patients with acute promyelocytic leukemia. Chin Med J (Engl) 127: 3503-3506, 2014.

5. Gallagher RE: Retinoic acid resistance in acute promyelocytic leukemia. Leukemia 16: 1940-1958, 2002.

6. Sanz MA and Montesinos P: How we prevent and treat differentiation syndrome in patients with acute promyelocytic leukemia. Blood 123: 2777-2782, 2014.

7. Kweon SH, Song JH, Kim HJ, Kim TS and Choi BG: Induction of human leukemia cell differentiation via PKC/MAPK pathways by arsantin, a sesquiterpene lactone from Artemisia santolina. Arch Pharm Res 38: 2020-2028, 2015.

8. Yi L and Su Q: Molecular mechanisms for the anticancer effects of diallyl disulfide. Food Chem Toxicol 57: 362-370, 2013.

9. Sundaram SG and Milner JA: Diallyl disulfide suppresses the growth of human colon tumor cell xenografts in athymic nude mice. J Nutr 126: 1355-1361, 1996.

10. Yi L, Ji XX, Lin M, Tan H, Tang Y, Wen L, Ma YH and Su Q: Diallyl disulfide induces apoptosis in human leukemia HL-60 cells through activation of JNK mediated by reactive oxygen. Pharmazie 65: 693-698, 2010.

11. Yi L, Ji XX, Tan H, Feng MY, Tang Y, Wen L and Su Q: Involvement of Mcl1 in diallyl disulfide-induced G2/M cell cycle arrest in HL-60 cells. Oncol Rep 27: 1911-1917, 2012.

12. Gharahdaghi F, Weinberg CR, Meagher DA, Imai BS and Mische SM: Mass spectrometric identification of proteins from silver-stained polyacrylamide gel: A method for the removal of silver ions to enhance sensitivity. Electrophoresis 20:601-605, 1999.

13. Ling H, Zhang LY, Su Q, Song Y, Luo ZY, Zhou XT, Zeng X, He J, Tan H and Yuan JP: Erk is involved in the differentiation induced by diallyl disulfide in the human gastric cancer cell line MGC803. Cell Mol Biol Lett 11: 408-423, 2006.

14. Lai KC, Hsu SC, Kuo CL, Yang JS, Ma CY, Lu HF, Tang NY, Hsia TC, Ho HC and Chung JG: Diallyl sulfide, diallyl disulfide, and diallyl trisulfide inhibit migration and invasion in human colon cancer colo 205 cells through the inhibition of matrix metalloproteinase-2, -7, and -9 expressions. Environ Toxicol 28: 479-488, 2013.

15. NagakuboD, Taira T,Kitaura H,Ikeda M,Tamai K, Iguchi-Ariga SM and Ariga H: DJ-1, a novel oncogene which transforms mouse NIH3T3 cells in cooperation with ras. Biochem Biophys Res Commun 231: 509-513, 1997.

16. Zhou X, Xu N,Li R, Xiao Y, Gao G, Lu Q, Ding L,Li L,Li Y, Du Q, et al: A comparative proteomic study of Homoharringtonineinduced apoptosis in leukemia K562 cells. Leuk Lymphoma 56: 2162-2169, 2015.

17. Liu H, Wang M, Li M, Wang D, Rao Q, Wang Y, Xu Z and Wang J: Expression and role of DJ-1 in leukemia. Biochem Biophys Res Commun 375: 477-483, 2008.

18. Bai J, Guo C, Sun W, Li M, Meng X, Yu Y, Jin Y, Tong D, Geng J, Huang Q, et al: DJ-1 may contribute to metastasis of non-small cell lung cancer. Mol Biol Rep 39: 2697-2703, 2012.

19. Lee H, Choi SK and Ro JY: Overexpression of DJ-1 and HSP90 $\alpha$, and loss of PTEN associated with invasive urothelial carcinoma of urinary bladder: Possible prognostic markers. Oncol Lett 3: 507-512, 2012.

20. Kim YC, Kitaura H, Taira T, Iguchi-Ariga SM and Ariga H: Oxidation of DJ-1-dependent cell transformation through direct binding of DJ-1 to PTEN. Int J Oncol 35: 1331-1341, 2009. 
21. VasseurS,Afzal S,Tomasini R, GuillaumondF, Tardivel-Lacombe J, Mak TW and Iovanna JL: Consequences of DJ-1 upregulation following p53 loss and cell transformation. Oncogene 31: 664-670, 2012.

22. Zhou J, Wang Y, Fei J and Zhang W: Expression of cofilin 1 is positively correlated with the differentiation of human epithelial ovarian cancer. Oncol Lett 4: 1187-1190, 2012.

23. Harris W, Sachana M, Flaskos J and Hargreaves AJ: Proteomic analysis of differentiating neuroblastoma cells treated with sublethal neurite inhibitory concentrations of diazinon: Identification of novel biomarkers of effect. Toxicol Appl Pharmacol 240: $159-165,2009$.

24. Heasman SJ and Ridley AJ: Mammalian Rho GTPases: New insights into their functions from in vivo studies. Nat Rev Mol Cell Biol 9: 690-701, 2008.

25. Koh SA, Kim MK, Lee KH, Kim SW and Kim JR: RhoGDI2 is associated with HGF-mediated tumor invasion through VEGF in stomach cancer. Clin Exp Metastasis 31: 805-815, 2014.

26. Fang Y, Yi J, Lizhi L and Qiucheng C: Rho GDP dissociation inhibitor beta promotes cell proliferation and invasion by modulating the AKT pathway in hepatocellular carcinoma. DNA Cell Biol 33: 781-786, 2014.

27. López-Pedrera C, Villalba JM, Siendones E, Barbarroja N, Gómez-Díaz C, Rodríguez-Ariza A, Buendía P, Torres A and Velasco F: Proteomic analysis of acute myeloid leukemia: Identification of potential early biomarkers and therapeutic targets. Proteomics 6 (Suppl 1): S293-S299, 2006.

28. Griner EM and Theodorescu D: The faces and friends of RhoGDI2. Cancer Metastasis Rev 31: 519-528, 2012.
29. Griner EM, Dancik GM, Costello JC, Owens C, Guin S, Edwards MG, Brautigan DL, Theodorescu D and Rho C: RhoC is an unexpected target of RhoGDI2 in prevention of lung colonization of bladder cancer. Mol Cancer Res 13: 483-492, 2015.

30. Zamanian M, Veerakumarasivam A, Abdullah S and Rosli R: Calreticulin and cancer. Pathol Oncol Res 19: 149-154, 2013.

31. Weng WC, Lin KH, Wu PY, Lu YC, Weng YC, Wang BJ, Liao YF, Hsu WM, Lee WT and Lee H: Calreticulin regulates VEGF-A in neuroblastoma cells. Mol Neurobiol 52: 758-770, 2015.

32. Lu YC, Weng WC and Lee H: Functional roles of calreticulin in cancer biology. Biomed Res Int 2015: 526524, 2015.

33. Caputo E, Maiorana L, Vasta V, Pezzino FM, Sunkara S, Wynne K, Elia G, Marincola FM, McCubrey JA, Libra M, et al: Characterization of human melanoma cell lines and melanocytes by proteome analysis. Cell Cycle 10: 2924-2936, 2011.

34. Qin H, Liu T, Yang JL, Huang X, Liu B, Song X, Zhao X and Wei YQ: Screening proteins related to retinoic acid resistance by proteomic analysis. Zhonghua Yi Xue Za Zhi 87: 520-525, 2007 (In Chinese).

35. Wang SC: PCNA: A silent housekeeper or a potential therapeutic target? Trends Pharmacol Sci 35: 178-186, 2014.

36. Zhu Q, Chang Y, Yang J and Wei Q: Post-translational modifications of proliferating cell nuclear antigen: A key signal integrator for DNA damage response (Review). Oncol Lett 7: 1363-1369, 2014

37. Calaf GM, Echiburú-Chau C, Wen G, Balajee AS and Roy D: Effect of curcumin on irradiated and estrogen-transformed human breast cell lines. Int J Oncol 40: 436-442, 2012. 